\title{
The Performance of Education System in Different Welfare Regimes in School to Work Transitions: Denmark, France, Spain, Greece, and Turkey
}

Çetin ÇELIKK (https://orcid.org/0000-0003-2992-4787), Department of Sociology, Koç University, Turkey; email: ccelik@ku.edu.tr

\section{Farklı Refah Devleti Modellerinde Eğitim Sisteminin Okuldan İş Piyasasına Geçişteki Performansı: Danimarka, Fransa, İspanya, Yunanistan ve Türkiye}

\begin{abstract}
School systems and their links with the labor market play an important role in students' success or failure and, consequently, facilitate (or not) their later access to the labor market. This article presents a comparison of the effects of different welfare regimes on school to work transitions. By drawing on an intense desk study and secondary analysis, the article examines five countries with different welfare regime types and reveals how they shape schooling and school to work transitions, particularly for disadvantaged groups. These countries are Denmark (universalistic regime), France (employment-centered regime), Spain, Greece, and Turkey (sub-protective regime). The article also addresses potential policy transfers in the findings.
\end{abstract}

Keywords

School Systems, Welfare State Typologies, School to Work Transitions, Education Policies.

JEL Classification Codes : I240, I250, I280.

$$
\text { Öz }
$$

Eğitim sistemleri ve eğitim sistemleri ile iş piyasası arasındaki bağlar öğrencilerin akademik başarısına ve okul sonrası iş piyasasına nasıl entegre olacaklarına hayati şekilde etki etmektedir. Yoğun ve karşılaştırmalı bir literatür çalışmasına ve ikincil kaynakların analizine dayanarak, bu makale farklı refah devleti modellerine sahip beş ülkeye odaklanmakta, bu modellerin okul sistemlerini ve okuldan iş piyasasına geçişi nasıl etkilediğini incelemektedir. Bu ülkeler sırasıyla evrenselci modele sahip Danimarka, istihdam merkezli modele sahip Fransa ve Güney Avrupa ${ }^{1}$ modeline sahip İspanya, Yunanistan ve Türkiye'dir. Makale bu ülkelerim içinde bulundukları refah devleti modellerinin okullaşma ve okuldan iş piyasasına geçiş sürecini özellikle dezavantajlı gruplar açısından incelemekte ve muhtemel politika aktarımlarını tartışmaktadır.

Anahtar Sözcükler : Okul Sistemleri, Refah Devleti Modelleri, Okuldan İş Piyasasına Geçiş, Eğitim Politikaları.

1 Makalede İspanya, Yunanistan ve Türkiye için “sub-protective” rejim ifadesi kullanılmaktadır. Söz konusu ifadenin Türkçe karşılığ bildiğim kadarıyla bulunmuyor. Bu yüzden, Türkçe öz kısmında, literatürde kavramla eş anlamlı kullanılan 'Güney Avrupa Modeli'kavramına yer verdim. 
Çelik, Ç. (2020), "The Performance of Education System in Different Welfare Regimes in School to Work Transitions: Denmark, France, Spain, Greece, and Turkey”, Sosyoekonomi, Vol. 28(45), 49-61.

\section{Introduction}

Since 2007-2008, recurring economic and financial crises and neoliberal policies have made transitions among life courses for individuals incredibly fragile and insecure (Colombo \& Rebughini, 2019). While these transitions have become unpredictable for everyone, they are more so for certain groups, particularly immigrants, refugees, and women (Çelik et al., 2019). Different welfare regimes, however, give distinctive reactions to the insecuritization of life course transitions such as school to work (STW) transition. They function as an intermediary layer between individuals and global forces, protecting the rights of their beneficiaries to different degrees. Among others, education systems and policies, in particular, are of critical importance for regulating transitions from school to the labor market (West \& Nikolai, 2013).

Welfare state models and their structuring effects on the lives of individuals are one of the most studied phenomena in the literature. These studies often document labor rights, retirement policies, or labor market regulations. However, the link between welfare state models and education systems is somewhat neglected. It is often the case that education systems are compared without reference to the welfare state models that shape them.

Turkey is one of the typical representative of a sub-protective regime which is mainly characterized by low percentage of standard workplaces and weak vocational training. The effectiveness and quality of education have long been severely criticized in Turkey. Various studies have documented that, parallel to the neoliberal restructuring of the education system, the capacity of schools for cultivating critical thinking and skill formation has deteriorated over the years (Gök, 2002; Rankin \& Aytac, 2006; ERG, 2010, 2011, 2014). However, as it will be explained later, the political struggles in the field of education between secularist and conservative Islamist forces further weakened the quality and credibility of vocational education and effectivity of STW in Turkey. This paper aims to bring a comparative perspective on the performance of education systems regarding the transition from school to the labor market. This perspective can inform us about potential policy transfers to reform the Turkish education system.

In the following, the article first groups the countries under specific types of welfare regimes. In this grouping, France represents a typical employment-centered regime, Denmark exemplifies an ideal universalistic regime, and Turkey, Spain, and Greece typify a standard sub-protective regime. Afterward, this article evaluates these country cases concerning the performance of their education systems and policies, particularly for STW transitions in recent times. In doing so, the paper seeks to sketch the weaknesses and strengths of each regime type. In the conclusion, the paper assesses these findings in relation to the reform debates around the Turkish education system.

\section{Method}

This article relies on a secondary analysis of documents collected as part of a larger project on the STW transitions of youth in Europe funded by the European Union's Seventh 
Çelik, Ç. (2020), "The Performance of Education System in Different Welfare Regimes in School to Work Transitions: Denmark, France, Spain, Greece, and Turkey", Sosyoekonomi, Vol. 28(45), 49-61.

Framework Programme (Grant ID 613256). The study, called Strategic Transitions for Youth Labor in Europe (STYLE), aims to examine the obstacles and opportunities affecting youth employment in Europe. The STYLE project lasted around three years, from March 2014 to September 2017. The primary aim of the STYLE project was to provide a comprehensive understanding of the causes of very high unemployment among young people and to assess the effectiveness of labor market policies designed to mitigate this phenomenon. It included 25 research partners, an international advisory network, local advisory boards of employers, unions, policymakers, and NGOs from over 20 European countries ${ }^{2}$.

In this project, the partners mainly collected data through desk studies. The collected data was compiled in order to achieve 10 different objectives, organized around 12 research, dissemination, and management work packages. These work packages included themes such as providing a critical evaluation of country and regional performance and assessing the prospects for policy transfer mechanisms.

With this purpose in mind, I investigated the education policies and systems for each country in depth and comparatively. Doing this provided valuable insight into the underlying conditions and logic at the policy [making] and institutional levels. National education systems face incredible challenges in times of crisis. Founded on and governed by different - often implicit - principles of fairness, the education systems are the representative of different welfare regimes. I conducted a profound document analysis that included policy documents, reports and policy briefs, and academic publications, particularly on the STW transition. As studies on youth unemployment and welfare regime types span a long period of time, I did not limit collection of the documents to a specific time frame.

In order to reveal and interpret the parallels and contrasts among STW policies, analysis of the models and policies was implemented in three parts, following the Policy Cycle Framework: an analysis of a policy's context of influence, context of policy text production and context of practices and effects (Bowe et al., 2017). I added global influences as a layer to this framework, because EU level programs are incredibly important in shaping youth policies at the local and national levels (Vidovich, 2007). Within this context of analysis, our documents included policy documents and academic articles at the local, national and supranational level for each country. In this way, I could understand the ways in which multilayered policies shape STW policies and the organization of education systems. Finally, I focused on the manifestations of these policies in the context of their effects and practices. I again used documents such as policy briefs, reports, academic articles, and blogs to understand the types of outcomes these polices generated in practice in various contexts. 
Çelik, Ç. (2020), "The Performance of Education System in Different Welfare Regimes in School to Work Transitions: Denmark, France, Spain, Greece, and Turkey”, Sosyoekonomi, Vol. 28(45), 49-61.

I used a qualitative content analysis technique in the document analysis. I searched for specific keywords in the documents, those most likely to indicate an interest in the topics of STW and welfare regime type in the relevant countries, such as apprenticeship, vocational education, training, qualifications, training programs, Not in Education, Employment or Training (NEET), and so on. Then, I read the context within which these keywords were used and collected the passages to be used for qualitative analysis. Based on this, as it will be explained below, I formed typologies concerning welfare regime responses in relation to STW. As the final stage, the countries were classified into certain welfare regime types and their performances reviewed.

\section{How Do Countries Perform in STW Transitions}

This section focuses on five countries that constitute three typical welfare regimes. It examines Denmark, France, Spain, Greece, and Turkey, clarifies why they typify different welfare regimes, and explain their weaknesses and strengths as to STW transitions.

\subsection{Denmark}

Denmark is a social-democratic welfare model that places individual rights and responsibilities within collective social responsibility. It represents the universalistic regime, characterized by a comprehensive education system with minimal streaming and flexible training possibilities (Esping-Andersen, 1996). Counseling is highly institutionalized in all stages of education, training, and employment, and it thus facilitates STW transitions (Walther, 2006). Compared to many other European economies, Danish youth have indeed experienced relatively low long-term (over one year) youth unemployment rates during and after the global financial crisis of 2007-2008, 14.2\% in 2011, which is much lower than the EU average of $22.8 \%$ (Crowley et al., 2013). The compulsory education dropout rate is low, around 5\%. Active Labor Market Policies (ALMP) and the prominent position of Vocational Education and Training (VET) systems should be particularly emphasized in the relatively low dropout out and youth unemployment rates. Among OECD countries, Denmark reserves the highest proportion of GDP for policies such as improving and supporting job search programs and improving qualifications and employability through vocational training and education (Carstensen \& Ibsen, 2015). The VET is based on the combined dual training principle in school and at work. With the high involvement of employers in training, the VET system turns into a collectivist skill formation system (Crowley et al., 2013).

Despite these achievements, the link between the socioeconomic background and education trajectory of children is still stronger in the Danish education system than the Swedish and Finnish. Compared to their native Danish peers, immigrant students face greater challenges in reaching high performance levels in compulsory education and successfully completing upper secondary education. For example, only $39 \%$ of students from a disadvantaged background are expected to complete the VET program, whereas this rate is $51 \%$ for native Danish students and, comparatively, the completion rates are higher for immigrant females (47\%) than males $(30 \%)$, which shows that the latter group is particularly disadvantaged in education (Nusche et al., 2010). 
Çelik, Ç. (2020), "The Performance of Education System in Different Welfare Regimes in School to Work Transitions: Denmark, France, Spain, Greece, and Turkey", Sosyoekonomi, Vol. 28(45), 49-61.

A lack of apprenticeship positions in companies is argued to cause many students, particularly males with immigrant backgrounds, to drop out before getting a degree; only half of the students enrolled in vocational training complete the program (Ingholt et al., 2015). The scarcity of company-based apprenticeship hinders programs from attracting the best and brightest students, which has gradually resulted in VET being seen a sort of dead end for young people - an option for those who cannot manage a tertiary education. Taken together, these have hurt the reputation of vocational education (Cederberg \& Hartsmar, 2013).

In order to address these challenges and increase quality, the Danish VET was reformed in 2014 - initiative called "Better and more attractive vocational education." The reform aims to improve the reputation of vocational education. However, the introduction of grade requirements to enter vocational education undermines its role of social integration for youth from working-class and disadvantaged backgrounds (Carstensen \& Ibsen, 2015). Because of this, young people with low-income parents or of immigrant backgrounds leave education without any certificates more often, which further marginalizes them in the labor market (Rasmussen \& Jensen, 2014).

\subsection{France}

Unlike Denmark, France represents an employment-centered regime, in which the state, despite becoming less prominent due to recent deregulation, privatization and decentralization processes, greatly shapes the STW transition as the key stakeholder (Walther, 2006). Here, compared to the Danish universal regime that offers broad second chance options to individuals to orient them toward regular and recognized options, the French employment-centered model tends to associate youth's labor market incapacity with learning and social deficits (Walther, 2006).

Comparatively, youth unemployment is at high levels in France: $23.8 \%$ in France and $16.3 \%$ in OECD countries overall in 2013 (OECD, 2014). Youth unemployment is particularly damaging for youth from disadvantaged, working-class, and ethnic minority backgrounds (Manfredi et al. 2010). The French labor market is polarized between the highly protective Contract of Indefinite Duration (CID) and more precarious Contract Duration Indetermine (CDD). Those who do not achieve a baccalaureate generally cumulate in jobs with CDD contracts (Smith et al., 2015). The strong link between socioeconomic background and academic achievement in the French education system is quite strong. The children of North African, sub-Saharan African, and Turkish immigrants fail and leave school more often than their French counterparts, and this results in their concentration in jobs offering the second type of contract (CDD) in the market (Alba et al., 2011).

Recent policy innovations such as "The hope for the Suburbs plan", "The Emergency Plan for Youth Employment", and the "Acting for Youth" plan have specifically targeted young people from underprivileged areas (banlieues), particularly early dropouts with a migrant or ethnic minority background (Eurofond, 2014). This particular focus can also be interpreted to mean that youth unrest in French banlieue in 2005 and the social tensions they 
Çelik, Ç. (2020), "The Performance of Education System in Different Welfare Regimes in School to Work Transitions: Denmark, France, Spain, Greece, and Turkey”, Sosyoekonomi, Vol. 28(45), 49-61.

caused is an essential trigger for policy actions in France (Audebert, 2013). It is interesting to note that the youth who joined in this unrest specifically targeted schools for pillage and arson, thereby suggesting that they were angry at broken promises regarding social mobility (Siberman, 2011).

In addition to several programs at various scales at the national level, some programs have also been initiated at a supranational level in France in order to combine education and training with employment, guidance, and counseling for disadvantaged young jobseekers, such as the well-known "Youth Guarantee" (YG) program and the Ecole de Deuxieme Chance - Second Opportunity School. Despite some positive results, evaluations of these solutions show that they are expensive and inefficient in the long run (Roger \& Zamora, 2011). The weak involvement of French employers in the STW system and "institutional stasis" that stem from the central role of the state have been highlighted as the main barriers to policy transfer and implementation (Smith et al., 2015).

\subsection{Spain}

Together with other Southern European countries such as Italy, Portugal and Greece, Spain is representative of a sub-protective transition regime, which is typically characterized by a low percentage of standard workplaces and a high share of unprotected living conditions (Walther, 2006). Therefore, the family and informal economy play significant roles in this regime type (Buchmann \& Kriesi, 2011). Typically, vocational training is not well developed, and the involvement of companies in vocational training is weak (Leccardi \& Ruspini, 2006).

Spain is indeed one of the countries that has been the most affected by the current economic crisis. There are about one million people between 15 and 24 years of age who are not employed, and the country has a youth unemployment rate of 53\%, which is more than double the 2012 EU average of 23\% (Eichhorst et al., 2013). The high dropout rate from compulsory secondary education almost doubles the EU average of 24.9\% (GonzálezMenéndez et al., 2015) and $20 \%$ of youth are NEET (Eichhorst et al., 2013). This creates a particularly fragile situation for low qualified youth.

The high dropout and NEET rates make STW transitions quite heterogeneous, nonlinear, and unpredictable (Bradley \& Devadason, 2008). Nevertheless, a close look at the sociodemographic characteristics of low qualified youth shows that these fragmented and individualized transitions are greatly shaped by structural conditions such as social class, gender, and ethnicity (Bell \& Blanchflower, 2010). Salvà-Mut et al. (2015) shows that unemployment is positively correlated with parents' low levels of education, particularly that of the mother, and a greater percentage of unemployed people were born in other countries, $26.2 \%$ vs. $15.3 \%$, with a significant number who were born in Africa, $15.4 \%$ vs. $2.1 \%$. They further note that $21.5 \%$ of young people without qualifications arrived between 2002 and 2009, primarily from countries outside the European Union, and could not get education or training, and unemployment is mainly a male phenomenon: $60 \%$ of males vs. $45.6 \%$ of females are unemployed (Salvà-Mut et al., 2015). 
Çelik, Ç. (2020), "The Performance of Education System in Different Welfare Regimes in School to Work Transitions: Denmark, France, Spain, Greece, and Turkey", Sosyoekonomi, Vol. 28(45), 49-61.

In response to these difficulties in the STW transition, a range of programs was developed at the national and international levels. Two important ones are the YG program - also present in France - created by the European Council and a dual apprenticeship system in specific regions modeled on the German system. YG particularly targets youth between 16 and 25 years old and aims to ensure that they receive an offer of employment, education, or training within four months of becoming unemployed or leaving school. However, it is doubtful whether YG will generate the expected results because funding reserved for the program is scarce and there is difficulty reaching the target demographic, as youth often move and may not even hear about the program (Cabasés Piqué \& Pardell Veà \& Strecker, 2015).

\subsection{Greece}

Similar to Spain, Greece bears the typical characteristics of the sub-protective STW regime and, similar to Spain, has also been the most adversely affected by the economic crisis. However, unlike Spain, youth unemployment was already high in Greece, even before the recession. It was $22.9 \%$ in 2007 , when the EU average was $15.7 \%$, and rose to a dreadful high of 58.3\% in 2013, when the EU average was 23.4\% (Petmesidou \& Polyzoidis, 2015). The crisis dramatically increased unemployment across all working-age groups.

Greece is another country where there is a strong link between family background and school achievement (Van de Werfhorst \& Mijs, 2010). However, regional differences in relation to educational inequalities are particularly striking (Martins \& Veiga, 2010). The dropout rates, employment, and living standards vary greatly between regions (Kyridis et al., 2011). Socially disadvantaged groups, such as Roma, repatriates, immigrants, and members of the Muslim minority of Thrace, densely populate regions that have high dropout rates and unemployment (Spinthourakis et al., 2008). The low educated and low qualified youth, which includes mostly minority youth, has been hit particularly hard by the recession, in which jobs in the manufacturing and retail trade sectors evaporated (Petmesidou \& Polyzoidis, 2015).

However, unlike many other European countries, low qualified youth is not the only group severely affected by the recession in Greece. Strikingly, Greek youth with tertiary education have also been of significant concern both before and after the crisis due to the long-term qualification mismatch between degrees and jobs in the STW regime. However, the crisis further exacerbated the qualification mismatch, as a high number of university graduates took jobs requiring only low qualifications and leading to a significant amount of brain drain as well-qualified Greeks sought to emigrate elsewhere (Petmesidou \& Polyzoidis, 2015). Additionally, it is worth noting that there is a substantial gender difference in the Greek STW transition regime. Females, ceteris paribus, face a significantly higher probability of unemployment at every level compared to men with similar characteristics (Mitrakos et al., 2010).

The high unemployment rates resulted in a range of devastating outcomes for Greek society, such as increased suicide rates. While the suicide rate increased for males aged 
Çelik, Ç. (2020), "The Performance of Education System in Different Welfare Regimes in School to Work Transitions: Denmark, France, Spain, Greece, and Turkey", Sosyoekonomi, Vol. 28(45), 49-61.

between 45 and 89 , it is interesting to note that remittances have suicide-reducing effects on the youth and female population (Antonakakis \& Collins, 2014). Widespread unemployment, combined with neoliberal restructuring of the education system and concerns about the impacts of the crisis, resulted in large-scale civil unrest in December 2008 in Greece (Sotiris, 2010).

In response to these difficulties, a range of policy programs has been initiated in or transferred to Greece, such as VET reform based on a German-Greek agreement, a mutual learning program, and YG, to improve the practical skills of young job seekers. Although some studies show that unemployed women, in particular, who joined vocational training consider these programs beneficial for skill formation despite their shortcomings (Panitsidou et al., 2012), the data is still too scarce to evaluate the effects of these policies. It should also be noted that there is widespread pessimism among experts about the potential success of these policy transfer programs in the context of deep economic crises (Petmesidou \& Polyzoidis, 2015).

\subsection{Turkey}

Turkey mostly shares the characteristics of the sub-protective STW regime with Spain and Greece. However, compared to these countries, the youth unemployment rate did not rise in parallel to the economic recession. It grew from 19\% in 2009 to $25 \%$ in 2011 but dropped back to $18.7 \%$ in 2013 (OECD, 2014). Yet, the crises notably increased the share of inactive youth; Turkey has the highest proportion of NEETs among 15- to 29- year-olds, at $29.2 \%$ (Carcillo et al., 2015).

The Turkish education system generates inequalities in various ways. Children's socioeconomic background strongly affects their educational career at every level. Students from poor households more often receive low-quality education, perform low academically, and drop out of school without any diploma (Dincer \& Kolasin, 2009). There is a lack of data on the ethnic background of dropouts. However, the fact that the rates are higher in regions densely populated by Kurdish people is quite telling about the ethnic dimension of the issue (ERG, 2011).

Early streaming into hierarchically ordered high school types through central exams at grades 6,7, and 8 increases the effect of family resources on academic achievement and causes the concentration of students from disadvantaged backgrounds in less prestigious vocational high schools. Given that vocational high school graduates, aged 18-24, make up only $16 \%$ of the employed population (Goksen et al., 2015), it becomes clear that this school type does not offer a secure transition to employment. Moreover, vocational schools are also a means to segregate girls into a gendered education, which reproduces gender inequality.

The quality of the vocational education and effectivity of STW has been worsened by the political struggles in the field of education between secularist and conservative Islamist forces. The secular coalition government introduced eight years of compulsory education in 1997 to block the entrance of students from primary schools to the lower 
Çelik, Ç. (2020), "The Performance of Education System in Different Welfare Regimes in School to Work Transitions: Denmark, France, Spain, Greece, and Turkey”, Sosyoekonomi, Vol. 28(45), 49-61.

secondary section of religious Imam Hatip Schools. This significantly lowered the prestige of vocational schools in general and changed its student profile in a negative way. The conservative Justice and Development Party (Adalet ve Kalkınma Partisi, AKP) introduced $4+4+4$ compulsory education in 2013 in reaction to this change, opening the way for students to attend these schools. Furthermore, the way the students are tracked into different high school types through early tracking has changed five times since 1997: the Exam for Transition to High Schools (Liselere Geçiş Sinavı, LGS) in 1997, the Secondary Education Selection and Placement Exam (Ortaögretim Kurumları Seçme ve Yerleştirme Sınavı, OKS) in 2005, Placement Test (Seviye Belirleme Sinavı, SBS) in 2008, Transition from Primary to Secondary Education (Temel Eğitimden Ortaöğretime Geçiş, TEOG) in 2013, the System for Transition to High Schools (Liselere Geçiş Sistemi, LGS) in 2018. As a result, the role of vocational schools in connecting youth to the labor market has become increasingly dysfunctional, as socioeconomically disadvantaged students and comparatively lower qualified teaching staff have increasingly been concentrated within these schools.

In responding to these issues, some social assistance programs have been transferred in or developed, such as conditional cash transfers, which, for poor households, have played a role in encouraging school enrollment of girls and boys (Adato \& Bassett, 2009). Additionally, there are also apprenticeship programs for those who have left formal education. A few guaranteed employment programs designed and run by certain associations, such as the Turkish Aeronautical Association, or by large industrial conglomerates, such as Koc holding and Sabanc1 holding, also exist. Apart from these exceptional cases, however, the centralized structure, low social status, and male-dominated structure of apprenticeships result in the rigid and inefficient functioning of the programs (Goksen et al., 2015). Overall, Turkey lacks a comprehensive youth policy approach that takes youth's needs and prospects as a focal issue and creates and coherently coordinates policies and institutions.

\section{Conclusions}

This paper presented the performance of education systems concerning STW transitions in five countries from three different welfare regimes. This review reveals that, despite its weaknesses, the universal regime - with its comprehensive education system, minimal streaming, and flexible training possibilities - performs best comparatively. Delayed streaming and the integration of companies into vocational education are critical issues for lessening insecurity and facilitating more successful STW transitions. These results are highly telling for debates around the design of the Turkish education system in recent years.

The French employment-centered model tends to explain problems in the STW transition as resulting from the incapacity of youth. However, the low level of employer involvement constitutes an enormous barrier to the smooth integration of youth into the labor market after finishing school. The rather slow implementation of programs or policy transfers in France due to the central position of the state in regulations should also be noted. While they represent different welfare regime types, Turkey and France have many parallels 
concerning program implementation. Like France, Turkey also suffers from rigid and inefficient program implementation due to the central position of the state. Again, while it has improved recently, employer involvement with vocational education is still low in Turkey.

Spain, Greece, and Turkey represent the sub-protective welfare regime type. These countries converge with each other concerning the absence of standard work packages, unprotected living conditions and the informal market. In this regime type, families and communities often act to compensate for the failures of the market and incapacities of the state concerning education and employment. The crisis impacted Greece and Spain badly, as they already had high youth employment. Compared to the other two, Turkey is characterized by a high percentage of NEETs. The comparative analysis of the subprotective regime countries highlights the low quality of training programs and the very weak company involvement with vocational training. It should be noted that with regard to disadvantaged groups, the situation may be more worrisome in Turkey, but there is no reliable data available about this issue to infer consistent conclusions.

These findings from the comparative analysis of three different welfare regime types and school systems are highly relevant for Turkey, where there is high youth unemployment and the highest NEET rate among OECD countries. The Turkish education system has been severely criticized, not only by politicians and experts but also by parents and students (KONDA, 2019). While the clear majority of the population still sees education as the primary and most legitimate component of social mobility, they also consider it a service the state should provide. However, we observe that the state has rapidly withdrawn from the field of education, privatizing it (İnal \& Akkaymak, 2012). Combined with early tracking, the rapid privatization results in resources drying up for state schools, driving more and more students into private schools, thereby deepening social inequalities.

Additionally, despite its critical importance for the STW transition, the vocational high school type is the least prestigious among parents and students. Given its high dropout and low job placement rates, this does not come as a surprise. There is an urgent need for reforms to increase the reputation of vocational schools, such as proper counseling services, curriculum reforms, and involving companies in curriculum design or partnerships for apprenticeship programs for effective and just apprenticeship opportunities. Otherwise, this school type will continue to generate high dropout rates and its graduates will be marginalized in the labor market.

Finally, the comparative findings suggest that steps should be taken to abolish early tracking in education. After the abolition of TEOG, and contrary to opposing claims, the system still sorts students into different high school types at the end of lower secondary education. Early tracking increases the effects of material and nonmaterial family resources on the academic achievement of children and thereby significantly intensifies academic and life inequalities. An education system that is characterized by more inclusive policies and late tracking is needed for a less fragile and more secure transition to the labor market. 
Çelik, Ç. (2020), "The Performance of Education System in Different Welfare Regimes in School to Work Transitions: Denmark, France, Spain, Greece, and Turkey", Sosyoekonomi, Vol. 28(45), 49-61.

\section{References}

Adato, M. \& L. Bassett (2009), "Social Protection to Support Vulnerable Children and Families: The Potential of Cash Transfers to Protect Education, Health and Nutrition", AIDS Care, 21(sup1), 60-75.

Alba, R. \& J. Sloan \& J. Sperling (2011), "The Integration Imperative: The Children of Low-Status Immigrants in the Schools of Wealthy Societies", Annual Review of Sociology, 37(1), 395-415.

Antonakakis, N. \& A. Collins (2014), "The Impact of Fiscal Austerity on Suicide: On the Empirics of a Modern Greek Tragedy”, Social Science \& Medicine, 112(July), 39-50.

Audebert, C. (2013), "The Social Geography of Ethnic Minorities in Metropolitan Paris: A Challenge to the French Model of Social Cohesion?", Patterns of Prejudice, 47(3), 309327.

Bell, D.N.F. \& D.G. Blanchflower (2010), “Youth Unemployment: Déjà Vu?”, IZA Discussion Paper Series, 4705.

Bowe, R. \& S.J. Ball \& A. Gold (2017), "The Policy Process and the Processes of Policy", in: R. Bowe \& S.J. Ball \& A. Gold (eds.), Reforming Education and Changing Schools: Case Studies in Policy Sociology, 1-18.

Bradley, H. \& R. Devadason (2008), “Fractured Transitions: Young Adults' Pathways into Contemporary Labour Markets", Sociology, 42(1), 119-36.

Buchmann, M.C. \& I. Kriesi (2011), "Transition to Adulthood in Europe", Annual Review of Sociology, 37(1), 481-503.

Cabasés Piqué, M.À. \& A.P. Veà \& T. Strecker (2015), "The EU Youth Guarantee - a Critical Analysis of Its Implementation in Spain”, Journal of Youth Studies, October 1-21.

Carcillo, S. \& S. Königs \& A. Minea \& R. Fernández (2015), "NEET Youth in the Aftermath of the Crisis", OECD Social, Employment and Migration Working Papers, 164, $<$ http://www.oecd-ilibrary.org/social-issues-migration-health/neet-youth-in-theaftermath-of-the-crisis_5js6363503f6-en>, 23.08.2019.

Carstensen, M.B. \& C.L. Ibsen (2015), "Barriers to and Triggers of Policy Innovation and Knowledge Transfer in Denmark", WP4.1/DK, <http://www.styleresearch.eu/publications/working-papers>, 23.08.2019.

Cederberg, M. \& N. Hartsmar (2013), "Some Aspects of Early School Leaving in Sweden, Denmark, Norway and Finland", European Journal of Education, 48(3), 378-89.

Çelik, Ç. \& F. Gökşen \& A. Filiztekin \& İ. Öker \& M. Smith (2019), "Fragile Transitions from Education to Employment: Youth, Gender and Migrant Status in the EU", in: E. Colombo \& P. Rebughini (eds.), Youth and the Politics of the Present: Coping with Complexity and Ambivalence, 1 Edition, Routledge Advances in Sociology, New York: Routledge.

Colombo, E. \& P. Rebughini (2019), Youth and the Politics of the Present: Coping with Complexity and Ambivalence, 1 Edition, Routledge Advances in Sociology, New York: Routledge.

Crowley, L. \& K. Jones, \& N. Cominetti \& J. Gulliford (2013), International Lessons: Youth Unemployment in the Global Context, The work foundation, Lancaster University. 
Çelik, Ç. (2020), "The Performance of Education System in Different Welfare Regimes in School to Work Transitions: Denmark, France, Spain, Greece, and Turkey", Sosyoekonomi, Vol. 28(45), 49-61.

Dinçer, M.A. \& G.U. Kolasin (2009), “Türkiye'de Öğrenci Başarısında Eşitsizliğin Belirleyicileri”, Ĕ̈itim Reformu Girişimi, <http://erg.sabanciuniv.edu/sites/erg.sabanciuniv.edu/files/BETAMRapor.pdf.>, 23.08.2019.

Eichhorst, W. \& H. Hinte, \& U. Rinne (2013), "Youth Unemployment in Europe: What to Do about It?", IZA Policy Paper, 65.

ERG (2010), PISA 2009 Sonuçlarına Ilişkin Değerlendirme.

ERG (2011), Eğitim İzleme Raporu 2010, <http://erg.sabanciuniv.edu/sites/erg.sabanciuniv.edu/files/EIR2010_SON.pdf>, 23.08.2019.

ERG (2014), “Türkiye PISA 2012 Analizi: Genel Bulgular ve Eğilimler”, Eğitim Reformu Girişimi.

Esping-Andersen, G. (1996), "Welfare States without Work: The Impasse of Labour Shedding and Familialism in Continental European Social Policy", in: Welfare States in Transition: National Adaptations in Global Economies, 66-87, 1 Oliver's Yard, 55 City Road, London EC1Y 1SP United Kingdom: SAGE Publications Ltd.

Eurofond (2014), Mapping Youth Transitions in Europe, Publications Office of the European Union. Gok, F. (2002), “The Privatisation of Education in Turkey”, in: N. Balkan \& S. Savran (eds.), Ravages of Neo-Liberalism: Economy, Society and Gender in Turkey, New York: Nova Science Publishers.

Goksen, F. \& D. Yukseker \& S. Kuz \& I. Oker (2015), "Barriers to and Triggers of Policy Innovation and Knowledge Transfer in Turkey", STYLE Working Papers WP4.1/TR. Brighton: CROME, University of Brighton.

González-Menéndez, M.C. \& F.J. Mato \& R. Gutiérrez \& A.M. Guillén \& B. Cueto \& A. Tejero (2015), "Policy Performance and Evaluation: Spain", WP3.3/ES. STYLE Working Papers, Brighton: CROME, University of Brighton, <http://www.styleresearch.eu/publications/working-papers>, 23.08.2019.

İnal, K. \& G. Akkaymak (eds.) (2012), Neoliberal Transformation of Education in Turkey: Political and Ideological Analysis of Educational Reforms in the Age of AKP, First edition, Postcolonial Studies in Education, New York: Palgrave Macmillan.

Ingholt, L. \& B.B. Sørensen \& S. Andersen \& L. Zinckernagel \& T. Friis-Holmberg \& A.F. Vibeke \& C. Stock \& T. Tjørnhøj-Thomsen \& M.H. Rod (2015), "How Can We Strengthen Students' Social Relations in Order to Reduce School Dropout? An Intervention Development Study within Four Danish Vocational Schools", BMC Public Health, 15(1).

KONDA (2019), Aralık 2019 Barometresi, KONDA Araştırma ve Danışmanlık.

Kyridis, A. \& H. Tsakiridou \& C. Zagkos \& M. Koutouzis \& C. Tziamtzi (2011), "Educational Inequalities and School Dropout in Greece", International Journal of Education, 3(2).

Leccardi, C. \& E. Ruspini (eds.) (2006), A New Youth? Young People, Generations and Family Life, Aldershot, England; Burlington, VT: Ashgate.

Manfredi, T. \& A. Sonnet \& S. Scarpetta (2010), "Rising Youth Unemployment During the Crisis", OECD Social, Employment and Migration Working Papers, 106, <http://www.oecdilibrary.org/social-issues-migration-health/rising-youth-unemployment-during-thecrisis_5kmh79zb2mmv-en>, 23.08.2019.

Martins, L. \& P. Veiga (2010), “Do Inequalities in Parents' Education Play an Important Role in PISA Students' Mathematics Achievement Test Score Disparities?", Economics of Education Review, 29(6), 1016-33. 
Çelik, Ç. (2020), "The Performance of Education System in Different Welfare Regimes in School to Work Transitions: Denmark, France, Spain, Greece, and Turkey”, Sosyoekonomi, Vol. 28(45), 49-61.

Mitrakos, T. \& P. Tsakloglou \& C. Ioannis (2010), "Determining Factors of Youth Unemployment in Greece with Emphasis on Tertiary Education Graduates", Economic Bulletin, no. 33.

Nusche, D. \& G. Wurzburg \& B. Naughton (2010), OECD Reviews of Migrant Education Denmark, OECD.

OECD (2014), OECD Labour Force Statistics 2013, Paris: OECD Publishing.

Panitsidou, E. \& A.M. Vastaki \& E. Valkanos (2012), "Vocational Education and Training of Unemployed Women in Greece: An Initial Approach", Procedia - Social and Behavioral Sciences, 69(December), 1729-36.

Petmesidou, M. \& P. Polyzoidis (2015), "Barriers to and Triggers of Policy Innovation and Knowledge Transfer in Greece", WP4.1/GR, STYLE Working Papers, CROME, University of Brighton, Brighton, <http://www.style-research.eu/publications/workingpapers>, 23.08.2019.

Rankin, B.H. \& I.A. Aytac (2006), "Gender Inequality in Schooling: The Case of Turkey”, Sociology of Education, 79(1), 25-43.

Rasmussen, P. \& U.H. Jensen (2014), Equity Issues in Education: NESET Country Report: Denmark, Denmark: Aalborg University.

Roger, M. \& P. Zamora (2011), "Hiring Young, Unskilled Workers on Subsidized Open-Ended Contracts: A Good Integration Programme?", Oxford Review of Economic Policy, 27(2), 380-96.

Salvà-Mut, F. \& C. Thomás-Vanrell \& E. Quintana-Murci (2015), "School-to-Work Transitions in Times of Crisis: The Case of Spanish Youth without Qualifications", Journal of Youth Studies, October, 1-19.

Siberman, R. (2011), "The Employment of Second Generations in France: The Republican Model and the November 2005 Riots", in: R.D. Alba \& M.C. Waters (eds.), The next Generation: Immigrant Youth in a Comparative Perspective, 283-316, New York: New York University.

Smith, M. \& M.L. Toraldo, \& V. Pasquier (2015), "Barriers to and Triggers of Policy Innovation and Knowledge Transfer in France", STYLE Working Papers, WP4.1/FR, CROME, University of Brighton, Brighton, <http://www.style-research.eu/publications/workingpapers>, 23.08.2019.

Sotiris, P. (2010), "Rebels with a Cause: The December 2008 Greek Youth Movement as the Condensation of Deeper Social and Political Contradictions: Debates and Developments", International Journal of Urban and Regional Research, 34(1), 203-9.

Spinthourakis, J.A. \& E. Karatzia-Stavlioti \& G.E. Lempesi \& I. Papadimitriou (2008), Country Report: Greece. Educational Policies That Address Social Inequality, 6.1.2. EACEA Action, London: IPSE.

Van de Werfhorst, H.G. \& J.J.B. Mijs (2010), "Achievement Inequality and the Institutional Structure of Educational Systems: A Comparative Perspective", Annual Review of Sociology, 36(1), 407-28.

Vidovich, L. (2007), "Removing Policy from Its Pedestal: Some Theoretical Framings and Practical Possibilities", Educational Review, 59(3), 285-98.

Walther, A. (2006), "Regimes of Youth Transitions: Choice, Flexibility and Security in Young People's Experiences across Different European Contexts", Young, 14(2), 119-39.

West, A. \& R. Nikolai (2013), "Welfare Regimes and Education Regimes: Equality of Opportunity and Expenditure in the EU (and US)", Journal of Social Policy, 42(03), 469-93. 
Çelik, Ç. (2020), "The Performance of Education System in Different Welfare Regimes in School to Work Transitions: Denmark, France, Spain, Greece, and Turkey”, Sosyoekonomi, Vol. 28(45), 49-61. 